\title{
What is the Ideal Diversification
}

\section{Strategy?: Reconsideration of}

\section{Diversification Strategy Research of}

\section{Rumelt}

Kiyohiro OKI ${ }^{\text {a) }}$

\begin{abstract}
Rumelt (1974), one of the basic researches related to diversification strategy, reveals that Dominant-Constrained (DC) and Related-Constrained (RC) strategies make possible a higher level of corporate performance. However, Rumelt (1982) clarifies that these strategies are not necessarily the ideal diversification strategies, because the industry effect have an influence on the performance of companies in these research. This paper re-consolidates and re-examines the data in Rumelt (1974) to reveal that companies in the particular industry tend to adopt the particular strategy. For example, many of the companies that adopted an RC strategy (Related-Constrained firms), a strategy that was viewed as leading to high performance, were in the drug, chemical, and machinery (except electrical) industries.
\end{abstract}

Keywords: diversification strategy, Rumelt, industry effect, related diversification

\footnotetext{
a) Faculty of Commerce, Kansai University, okik@kansai-u.ac.jp

A part of this paper was originally published as Oki (2009) in Japanese.
} 


\section{Problem of Rumelt (1974)}

Diversification strategy is a key factor of corporate strategy. Those who study diversification at a university will undoubtedly be taught Rumelt's research as the basics in this field. Rumelt (1974), in addition to categorizing diversification strategies, clarified the relationship to company performance for each strategy using data from 246 American corporations.

While only the essence is taught in texts and courses, Rumelt's (1974) conclusions seem to stand on their own. The following are the conclusions that come to mind when considering Rumelt (1974):

1) The analysis showed that the strategies related to higher performance were the Dominant-Constrained (DC) and the Related-Constrained strategies (RC).

2) On the other hand, the Related-Linked (RL) firms exhibited average performance levels, while the Unrelated-Passive (UP) firms exhibited the worst performance.

3) ${ }^{1}$ Rather than diversifying into technologically unrelated areas, it is better to diversify into businesses close to the company's main business, in which it can utilize its core.

These conclusions are convincing. It is intuitively correct that it is better to diversify into related areas than diversify into unrelated areas. Based on this research, the ideal diversification strategies are the DC and RC strategies.

1 Particular attention needs to be paid to the conclusions about the unrelated diversification. Rumelt (1974) defines Unrelated-Passive companies as "unrelated businesses that do not qualify as Acquisitive Conglomerates." However, the definition for Acquisitive Conglomerate (AC) firms includes this performance related definition, "an average growth rate in earnings per share of at least 10 percent per year." Because of this, it is a matter of course that the UP firms within Rumelt (1974) have low performances. 
However, Rumelt (1982), which is his follow-up research of Rumelt (1974), revealed that these two strategies are not necessarily the ideal diversification strategies.

Rumelt (1982) performed the same analysis on data from 50 new companies in addition to the data from Rumelt (1974). The results showed no significant relationship between a DC diversification strategy and high performance (Rumelt, 1982, p. 362, Table 2). On the other hand, similar to findings of Rumelt (1974), a significant relationship was shown to exist between an RC strategy and high performance.

However, when the analysis included the industry effect, it was shown that the high performance of the RC strategy was mainly due to the industry effect.

In other words, it is not that the performance of companies adopting an RC strategy that is higher due to the superiority of the RC strategy, but that higher performance is exhibited because companies adopting the RC strategy are in more profitable industries. ${ }^{2}$ Was the industry effect also working in Rumelt (1974)? Or were different results obtained in Rumelt (1982) solely because of the additional data, and was Rumelt (1974) able to reveal the ideal diversification strategy at all?

In order to answer these questions, this paper re-consolidates and re-examines the data in Rumelt (1974) to check for bias between industries and particular diversification strategies.

2 In Rumelt (1982), unrelated diversified (UP and AC) firms were all classified as Unrelated Businesses (UB) firms, and analysis including industry impact was performed. As a result, there was a relationship between low performance and unrelated diversified firms that was not related to industry effects. However, some research points out that the industry effect may work in unrelated diversification (Grant, 2007; Grant \& Jammine, 1985). Because the focus of this paper is on DC and RC strategies, this paper will not discuss if industry bias is present in unrelated diversification strategies. 


\section{Was the Industry Effect at Work in Rumelt (1974)?}

Christensen and Montgomery (1981) is one of the earliest researches to suggest the possibility of the industry effect at work in Rumelt (1974). This research combined the data in Rumelt (1974) with later data from 1974 and analyzed it. This analysis showed that much of the difference between the performance of companies diversifying into related fields and the performance of companies diversifying into unrelated fields was explained by market growth, market concentration, and market structure. In other words, they argued that the correlation between particular strategies and performance was evidenced because of the relationships between strategy and market structure and between market structure and performance.

Christensen and Montgomery (1981) did not clearly touch on the industry effect, but suggested the industry effect because the market structure is influenced by the character of the industry. Rumelt was also aware of the industry effect and in his original research two corrections were actually examined to eliminate the industry effect (Rumelt, 1974, pp. 96-101).

The first was extracting the average profit margin for each industry classified by a three digit SIC code, and performing analysis using the difference between the industry profit margin and the company profit margin as a variable of company performance. The results of this analysis showed no significant relationship between diversification strategy and performance.

However, since there were quite a few companies in each three digit industry, this analysis has a sample bias. For example, the average profit margin of all sampled companies in a particular industry exceeds the average profit margin for the industry. Therefore, Rumelt pointed out that the analysis lacks rigor.

As a second correction, divisions of industries were made according 
to two digit SIC codes, and an attempt was made to add each industry to the performance analysis as a dummy variable. By so doing, multicollinearity was high, and analysis could not be done.

Rumelt attempted to perform the above corrections in order to eliminate the industry effect; however, he was unable to isolate the diversification effect from the industry effect. Rumelt (1974) affirmed in the following statements that industry and diversification effects cannot be separated:

The empirical evidence that Related-Constrained firms outperform Dominant-Vertical firms does not mean that Dominant-Vertical Companies should attempt to follow Related-Constrained Strategies... (Rumelt, 1974, p.101)

He also affirmed the following statements in the conclusions of the analysis:

...although many of the performance differences among the categories could be thought of as reflections of industry differences, the close connection between strategy, structure and the firm's economic environment makes it difficult to separate these effects, either conceptually or mathematically... (Rumelt, 1974, p. 123)

As suggested above, in 1974 Rumelt also understood the possibility that the results included an industry effect. However, it has never been examined whether or not the industry effect existed in the data in Rumelt (1974).

\section{Method}

This paper examines whether or not the industry effect existed in the data of Rumelt (1974). For the purpose, from the data in the appendix of Rumelt (1974), this paper clarifies that there are many companies adopting a particular strategy in their particular industry. 
Rumelt (1974) also organizes the frequency of the strategy for each industry based on the two digit SIC codes (Rumelt, 1974, pp. 98-99, Table 3-4, Table 3-5). In this table, the diversification strategy frequency in 1949 and 1969 is organized by industry.

However, these tables show total data gathered by Rumelt and is not the sample used in the analysis of diversification strategies. The actual sample used in the analysis is made up of companies that either did not change their diversification strategy from 1949 to 1959 , or from 1959 to 1969 , and is therefore smaller than the original data. Therefore, this paper re-creates the frequency data of diversification strategies by industry. However, regarding SIC codes, there was the problem of not knowing the classification codes used at the time.

Hence, the classification codes currently in use are adopted. ${ }^{3}$ However, there were 45 companies over two periods where it was unclear to which industry these companies belonged because of the ambiguity of SIC code. These companies was classified according to the subjective view of the author. ${ }^{4}$

Furthermore, in the table of Rumelt (1974), because the DC (Dominant-Constrained) firms, DL (Dominant-Linked) firms, and the

3 Refer to http://www.dnbtsr.com/database/images/SIC.pdf

4 This type of subjective classification could be a problem when distinguishing between the industry categories of electrical equipment and machinery (except electrical). The reason is that this paper indicates the prominence of the electrical equipment industry in DL and RL strategies in subsequent analysis. Therefore, this note shows that classifying these two industries subjectively is not a problem. Within the samples of industries defined subjectively, there were a total of five firms in these two terms that were classified as electrical equipment but could have been classified as machinery (except electrical). Among these, two firms adopted an RC strategy and three firms adopted an RL strategy. As subsequent research shows, because there were 10 other electrical equipment firms that adopted DL and RL strategies, even if those three firms had not been classified in the industry category of electrical equipment, there were still many firms in the electrical equipment industry category that adopted DL and an RL strategies strategy. Hence, even with industry classifications based on subjectivity, it does not detract from the purpose of this paper. 
Table 1. Frequency of diversification strategy by industry, 1949 and 1969 from author's classification

\begin{tabular}{|c|c|c|c|c|c|c|c|c|c|c|c|}
\hline SIC Industry & code & $\mathbf{s}$ & DV & DC & DU & DL & $\mathbf{R C}$ & $\mathbf{R L}$ & AC & UP & Total \\
\hline Metal mining & 10 & 0 & 0 & 1 & 0 & 0 & 0 & 0 & 0 & 0 & 1 \\
\hline $\begin{array}{l}\text { Bituminous \& } \\
\text { mignite mining }\end{array}$ & 12 & 0 & 0 & 0 & 0 & 0 & 0 & 0 & 3 & 0 & 3 \\
\hline $\begin{array}{l}\text { Mfr food \& kindred } \\
\text { products }\end{array}$ & 20 & 18 & 9 & 9 & 0 & 0 & 9 & 1 & 2 & 0 & 48 \\
\hline $\begin{array}{l}\text { Mfr tobacco } \\
\text { products }\end{array}$ & 21 & 2 & 0 & 0 & 2 & 0 & 0 & 0 & 1 & 0 & 5 \\
\hline $\begin{array}{l}\text { Mfr textile mill } \\
\text { products }\end{array}$ & 22 & 1 & 0 & 0 & 0 & 1 & 2 & 2 & 0 & 0 & 6 \\
\hline $\begin{array}{l}\text { Mfr apparel \& } \\
\text { related products }\end{array}$ & 23 & 2 & 0 & 0 & 0 & 0 & 0 & 0 & 0 & 0 & 2 \\
\hline $\begin{array}{l}\text { Mfr lumber \& wood } \\
\text { products }\end{array}$ & 24 & 0 & 5 & 0 & 0 & 0 & 1 & 0 & 0 & 0 & 6 \\
\hline $\begin{array}{l}\text { Mfr paper \& allied } \\
\text { products }\end{array}$ & 26 & 6 & 9 & 0 & 0 & 0 & 1 & 0 & 0 & 0 & 16 \\
\hline $\begin{array}{l}\text { Mfr printing \& } \\
\text { publishing }\end{array}$ & 27 & 2 & 0 & 2 & 0 & 0 & 0 & 0 & 0 & 0 & 4 \\
\hline $\begin{array}{l}\text { Mfr chemicals \& } \\
\text { allied products }\end{array}$ & 28 & 0 & 0 & 1 & 0 & 0 & 12 & 4 & 3 & 1 & 21 \\
\hline Drugs & 283 & 0 & 0 & 0 & 0 & 0 & 14 & 0 & 0 & 0 & 14 \\
\hline Soup \& toiletries & 284 & 0 & 0 & 3 & 0 & 0 & 0 & 0 & 0 & 0 & 3 \\
\hline $\begin{array}{l}\text { Mfr petroleum } \\
\text { refining \& related } \\
\text { ind. }\end{array}$ & 29 & 0 & 0 & 0 & 0 & 0 & 3 & 2 & 0 & 0 & 5 \\
\hline $\begin{array}{l}\text { Oil \& gas } \\
\text { extraction }\end{array}$ & 13 & 6 & 5 & 0 & 0 & 0 & 0 & 0 & 0 & 0 & 11 \\
\hline $\begin{array}{l}\text { Mfr rubber \& } \\
\text { plastic products }\end{array}$ & 30 & 0 & 8 & 0 & 0 & 0 & 2 & 0 & 0 & 0 & 10 \\
\hline $\begin{array}{l}\text { Mfr leather } \& \\
\text { leather products }\end{array}$ & 31 & 3 & 0 & 0 & 0 & 0 & 0 & 0 & 0 & 0 & 3 \\
\hline $\begin{array}{l}\text { Mfr stone clay \& } \\
\text { glass products }\end{array}$ & 32 & 1 & 0 & 1 & 0 & 2 & 5 & 2 & 0 & 0 & 11 \\
\hline $\begin{array}{l}\text { Primary metal } \\
\text { industries }\end{array}$ & 33 & 0 & 13 & 0 & 0 & 0 & 1 & 0 & 0 & 0 & 14 \\
\hline $\begin{array}{l}\text { Mfr fabricated } \\
\text { metal products }\end{array}$ & 34 & 5 & 7 & 1 & 0 & 0 & 1 & 0 & 0 & 0 & 14 \\
\hline $\begin{array}{l}\text { Mfr machinery } \\
\text { except electrical }\end{array}$ & 35 & 3 & 0 & 6 & 0 & 1 & 14 & 4 & 1 & 3 & 32 \\
\hline $\begin{array}{l}\text { Mfr electrical } \\
\text { equipment }\end{array}$ & 36 & 2 & 0 & 1 & 0 & 1 & 4 & 12 & 4 & 0 & 24 \\
\hline $\begin{array}{l}\text { Mfr transportation } \\
\text { equipment }\end{array}$ & 37 & 1 & 0 & 1 & 1 & 0 & 2 & 4 & 0 & 5 & 14 \\
\hline Aircraft & 372 & 1 & 0 & 5 & 0 & 0 & 4 & 1 & 1 & 3 & 15 \\
\hline $\begin{array}{l}\text { Mfr instruments } \\
\text { related products }\end{array}$ & 38 & 0 & 0 & 0 & 0 & 0 & 1 & 0 & 0 & 0 & 1 \\
\hline $\begin{array}{l}\text { Mfr manufacturing } \\
\text { industries }\end{array}$ & 39 & 0 & 0 & 0 & 0 & 0 & 3 & 0 & 1 & 0 & 4 \\
\hline Total & & 53 & 56 & 31 & 3 & 5 & 79 & 32 & 16 & 12 & 287 \\
\hline
\end{tabular}

Source: Rumelt (1974)

DU (Dominant-Unrelated) firms are listed together, as are the AC (Acquisitive Conglomerate) firms and UP (Unrelated-Passive) firms, we decided to separate them. Using this classification, Table 1 shows 
the sum of all of the companies actually used in the analysis. From this data, we examine which industries have more of the RC and DC strategies that were considered ideal according to Rumelt (1974).

\section{Result}

First, in relation to RC strategy, there are many in the following industries: food and kindred products, chemicals and allied products, drugs, and machinery (except electrical). Of the 79 companies that selected the RC strategy, 49 of them, or $60 \%$ of the total, are in one of the above industry categories. From this we can see that most of the companies adopting the RC strategy are in one of these four industry categories.

Also of the total 35 companies that belong to the chemical and allied products and drugs industries, 26 chose the RC strategy. We can see from this that there are many RC firms in certain industries. Next, we can see that of those adopting the DC strategy, many belong to the food and kindred products, machinery (except electrical), and aircraft categories.

However, we can consider that many companies adopt the DC strategy because the original sample size was high for the food and kindred products and machinery (except electrical) industry categories.

In order to more clearly understand the bias between these strategies and industries, we pair DC and RC strategies and compare them with the DL and RL strategies. We further classify the DC and $\mathrm{RC}$ strategies as $\mathrm{C}$ strategies (constrained strategy) and the DL and RL strategies as L strategies (linked strategy).

However, due to the difference in total number of samples between the C strategy and the L strategy, we aligned the total samples number with the samples numbers of $\mathrm{L}$ and $\mathrm{C}$ strategies (Table 2, Figure 1). 
Table 2. Frequency of C strategy and L strategy by industry

\begin{tabular}{lr|r|r|r}
\hline SIC Industry & code & \multicolumn{1}{l|}{ C } & \multicolumn{1}{c}{ L } & Adjusted C \\
\hline Metal mining & 10 & 1 & 0 & 0.34 \\
\hline Bituminous \& lignite mining & 12 & 0 & 0 & 0 \\
\hline Mfr food \& kindred products & 20 & 18 & 1 & 6.05 \\
\hline Mfr tobacco products & 21 & 0 & 0 & 0 \\
\hline Mfr textile mill products & 22 & 2 & 3 & 0.67 \\
\hline Mfr apparel \& related products & 23 & 0 & 0 & 0 \\
\hline Mfr lumber \& wood products & 24 & 1 & 0 & 0.34 \\
\hline Mfr paper \& allied products & 26 & 1 & 0 & 0.34 \\
\hline Mfr printing \& publishing & 27 & 2 & 0 & 0.67 \\
\hline Mfr chemicals \& allied products & 28 & 13 & 4 & 4.37 \\
\hline Drugs & 283 & 14 & 0 & 4.71 \\
\hline Soup \& toiletries & 284 & 3 & 0 & 1.01 \\
\hline Mfr petroleum refining \& related ind. & 29 & 3 & 2 & 1.01 \\
\hline Oil \& gas extraction & 13 & 0 & 0 & 0 \\
\hline Mfr rubber \& plastic products & 30 & 2 & 0 & 0.67 \\
\hline Mfr leather \& leather products & 31 & 0 & 0 & 0 \\
\hline Mfr stone clay \& glass products & 32 & 6 & 4 & 2.02 \\
\hline Primary metal industries & 33 & 1 & 0 & 0.34 \\
\hline Mfr fabricated metal products & 34 & 2 & 0 & 0.67 \\
\hline Mfr machinery except electrical & 35 & 20 & 5 & 6.73 \\
\hline Mfr electrical equipment & 36 & 5 & 13 & 1.68 \\
\hline Mfr transportation equipment & 37 & 3 & 4 & 1.01 \\
\hline Aircraft & 372 & 9 & 1 & 3.03 \\
\hline Mfr instruments related products & 38 & 1 & 0 & 0.34 \\
\hline Mfr manufacturing industries & 39 & 3 & 0 & 1.01 \\
\hline Total & & 110 & 37 & 37 \\
\hline Mote: Thealculation method is & & 0 \\
\hline
\end{tabular}

Note: The calculation method is "(the number of C strategy samples occurring in each industry) $\times$ (the total number of L strategy samples / the total number of $\mathrm{C}$ strategy samples)".

Here, the number of companies from the three industry categories of food and kindred products, drugs, and aircraft in the $\mathrm{C}$ strategy, which was determined to have better performance than the L strategy, is 3-6 times more in comparison to the L strategy. On the other hand, $30 \%$ of those choosing the L strategy are companies in the industry category of manufacturers of electrical equipment. This is a wide difference between $\mathrm{C}$ strategy companies and L strategy companies. In other words, we can see a relationship between strategy and industry.

Within these, the drugs industry category is of particular note. ${ }^{5}$

5 The heterogeneity of the drug industry has also been indicated from the perspective of product development (Kuwashima, 2003). 


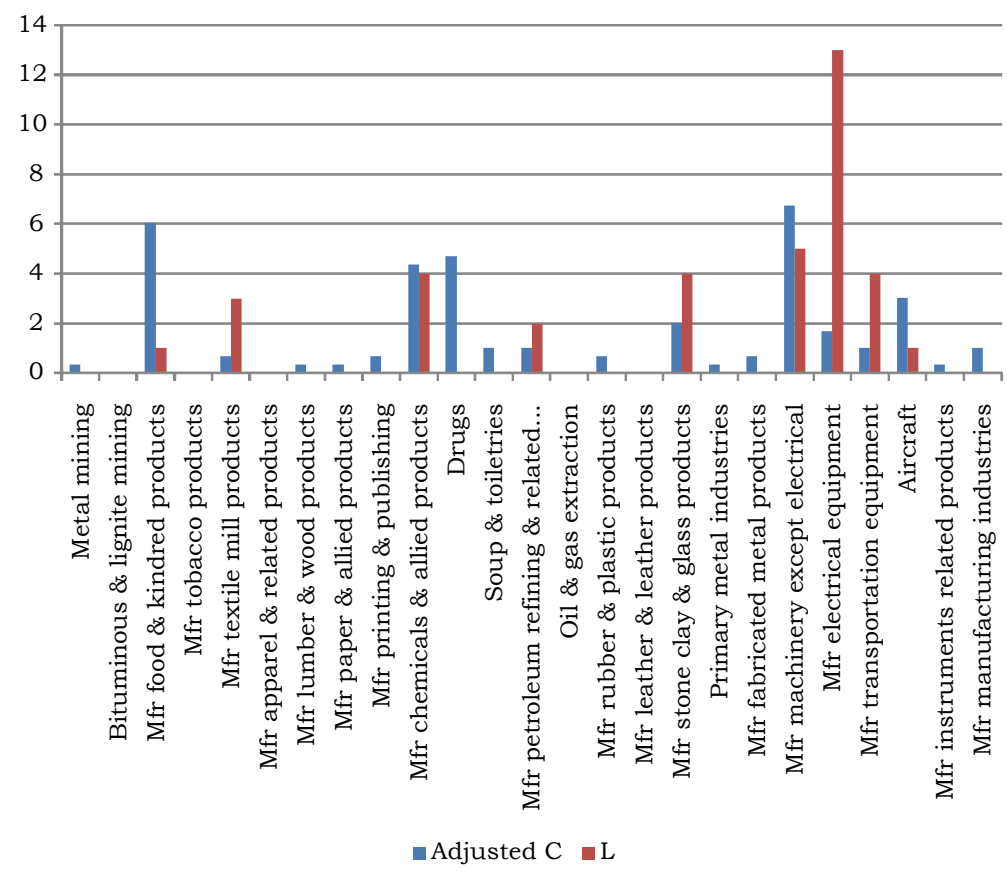

Figure 1. Frequency of adjusted C strategy and L strategy by industry

Most of the RC firms belong to the drugs industry category, and this industry is known for relatively high profit margins. Examination of data for Japanese companies suggests the possibility of the drug industry being a high profit industry since the 1960s. For example, the average ordinary profit margin for the ten pharmaceutical manufacturers in Japan (Takeda Pharmaceutical, Yamanouchi, Sankyo, Shionogi, Tanabe, Fujisawa Pharmaceutical, Eisai, Banyu, Daiichi Pharmaceutical, and Dainippon Pharmaceutical) was $15 \%$.

On the other hand, the average ordinary profit margin of the large companies in the electronic equipment industry (Matsushita, Hitachi, Toshiba, Mitsubishi, Sanyo, Nippon Electric, Sharp, Fujitsu, Sony, and Fuji Electric), many of which adopted the RL strategy in Rumelt 
(1974), was 9\%. The average ordinary profit margin of the drug industry was higher in Japan. The average ordinary profit margin of the highest profit margin companies in the drugs industry category exceeded 15\% (Takeda Pharmaceuticals, Dainippon Pharmaceuticals, Fujisawa Pharmaceuticals, and Yamanouchi Pharmaceuticals, etc.), however the highest profit margin in the electronic equipment industry was Fujitsu with $14 \%{ }^{6}$

In this manner, drug companies have the possibility of achieving high profit margins due to the industry.

Of course this is not the data of US companies, and is the only supporting evidence due to lack of clarity concerning profit margin trends prior to 1969. However, when considering the high level of technological skill needed to develop pharmaceuticals along with the existence of patents, the drug industry is thought to be one with high entry barriers since that time, as well as an industry with high profit margins.

The fact that many of the companies included in these industries adopted the RC strategy suggests a strong possibility that the relationship of the RC strategy to superior performance may be due to the industry effect.

\section{Future Research of Diversification Strategy}

The analysis in this paper clarifies that DC and RC firms in the data of Rumelt (1974) tend to belong to particular industries.

The data also has a strong possibility of the influence of the industry effect and Rumelt's research was not able to clarify an ideal diversification strategy.

What needs to be done in order to clarify the ideal diversification strategy? Based on the problems of Rumelt's research confirmed in

6 From each firm's financial statements. 
this paper, there is a need for analysis while controlling the industry effect.

One method is to devise variables, such as the analysis that incorporated a dummy variable for industry effect (Grant \& Jammine, 1985), or the analysis of Rumelt (1982), that adopted the difference in company profit margins and industry average profits as a performance variable.

Another method is to devise a way of taking samples.

Rumelt $(1974,1982)$ took random samples from across industries. The result, however, was the selection of many companies in particular industries adopting a particular strategy.

Therefore, either analyzing one specific industry or choosing companies whose strategies would not be biased to particular industries may also be effective.

However, explaining company performance based solely on industry and diversification is insufficient. Rumelt explains this in his later work (Rumelt, 1991). Rumelt (1991) reveals that corporate effects, industry effects, and business unit effects all have a major influence on company performance. This research did not address diversification, but suggested that distinctive resources of the business unit and position are important to company performance.

This argument of Rumelt (1991) is closely related to the resource based view (RBV) that takes into consideration that a company's individually accumulated resources and capabilities influence performance (Barney, 1991; Wernerfelt, 1984). Because research based on the RBV was not actively performed until after the 1990s, the company's resources were not reflected in Rumelt's diversification research. ${ }^{7}$

Based on these research trends, research into the relationship

7 In Japan, research has been carried out targeting the automotive industry based on RBV (Fujimoto, 1999; Heller \& Fujimoto, 2004; Konno, 2007). 
between performance and diversification that controls "resource effects" and "industry effects" is required.

Various attempts have been made to explain company performance due to a number of factors. For example McGahan and Porter (1997) clarified to what extent industry factors, company factors, and business unit factors each explain company performance.

In recent years there has been research utilizing multiple factors in attempting to clarify to what extent strategic groups explain company performance (Short, Ketchen, Palmer, \& Hult, 2007). However, much of this research does not aim to clarify the ideal diversification strategy.

In future research, we need to combine various factors with diversification strategy in order to specify "the ideal diversification strategy."

\section{References}

Barney, J. B. (1991). Firm resources and sustained competitive advantage. Journal of Management, 18, 99-120.

Barney, J. B. (2002). Gaining and sustaining competitive advantage (2nd ed.). Upper Saddle River, NJ: Prentice Hall.

Christensen, H. K., \& Montgomery, C. A. (1981). Corporate economic-performance: Diversification strategy versus market-structure. Strategic Management Journal, 2, 327-343.

Fujimoto, T. (1999). The evolution of a manufacturing system at Toyota. New York, NY: Oxford University Press.

Grant, R. M. (2007). Contemporary strategy analysis (6th ed.). Malden, MA: Blackwell.

Grant, R. M., \& Jammine, A. P. (1985). Performance differences between the Wrigley Rumelt strategic categories. Strategic Management Journal, 9, 327-343.

Heller, D. A., \& Fujimoto, T. (2004). Inter-firm learning in high-commitment horizontal alliances: Findings from two cases in the 
world auto industry. Annals of Business Administrative Science, 3, 35-52. doi: 10.7880/abas.3.35

Konno, Y. (2007). Enhancement of the advanced R\&D cooperation between automakers and suppliers in the Japanese automobile industry. Annals of Business Administrative Science, 6, 15-34. doi: $10.7880 /$ abas.6.15

Kuwashima, K. (2003). Organizational capability and competitive advantage in pharmaceutical product development. Annals of Business Administrative Science, 2, 21-28. doi: 10.7880/abas.2.21

McGahan, A. M., \& Porter, M. E. (1997). How much does industry matter, really? Strategic Management Journal, 18, 15-30.

Oki, K. (2009). Mezasubeki takakuka senryaku towa nandattanoka [What is the ideal diversification strategy?: Reconsideration of Rumelt's research]. Akamon Management Review, 9, 243-264 (in Japanese).

Porter, M. E. (1980). Competitive strategy: Techniques for analyzing industries and competitors. New York, NY: Free Press.

Rumelt, R. P. (1974). Strategy, structure and economic performance. Cambridge, MA: Harvard University Press.

Rumelt, R. P. (1982). Diversification strategy and profitability. Strategic Management Journal, 3, 359-369.

Rumelt, R. P. (1991). How much does industry matters? Strategic Management Journal, 12, 167-185.

Short, J. C., Ketchen, D. J., Jr., Palmer, T. B., \& Hult, G. T. M. (2007). Firm, strategic group, and industry influences on performance. Strategic Management Journal, 28, 147-167.

Wernerfelt, B. (1984). A resource-based view of the firm. Strategic Management Journal, 5, 171-180. 